\title{
Recombinant Expression and Purification of the Antimicrobial Peptide Magainin-2
}

\author{
Reinaldo Ramos, Susana Moreira, Ana Rodrigues, Miguel Gama, and Lucília Domingues \\ Institute for Biotechnology and Bioengineering (IBB), Centre of Biological Engineering, Universidade do Minho, \\ Campus de Gualtar, 4710-057 Braga, Portugal
}

DOI 10.1002/btpr.1650

Published online December 4, 2012 in Wiley Online Library (wileyonlinelibrary.com).

Magainin-2 (MAG2) is a polycationic antimicrobial peptide isolated from the skin of the African clawed frog Xenopus laevis. It has a wide spectrum of antimicrobial activities against gram-positive and gram-negative bacteria, fungi, and induces osmotic lysis of protozoa. MAG2 also possesses antiviral and antitumoral properties. These activities make this peptide a promising candidate for therapeutic applications. Recombinant expression systems are necessary for the affordable production of large amounts of the biologically active peptide. In this work, MAG2 has been cloned to the N-terminal of a family III carbohydratebinding module fused to the linker sequence ( $L K$-CBM3) from Clostridium thermocellum; a formic acid recognition site was introduced between the two modules for chemical cleavage of the peptide. The recombinant protein MAG2-LK-CBM3 was expressed in Escherichia coli BL21 (DE3) and MAG2 was successfully cleaved and purified from the fusion partner LK-CBM3. Its functionality was confirmed by testing its activity against gram-negative bacteria. (C) 2012 American Institute of Chemical Engineers Biotechnol. Prog., 29: 17-22, 2013

Keywords: Magainin-2, Recombinant protein, antimicrobial peptide

\section{Introduction}

Bacterial resistance to antibiotics, first noticed back in the 1950 s, is a growing concern for public health. ${ }^{1}$ Because of their mechanism of action, the antimicrobial peptides (AMPs) represent an attractive alternative as human therapeutics. AMPs are part of the innate immune system and represent an important component of immune defense. They have a large spectrum of antimicrobial activities against gram-positive and gram-negative bacteria, fungi, ${ }^{2}$ and viruses like influenza $\mathrm{A}^{3}$ or human immunodeficiency virus (HIV-1). ${ }^{4}$ Moreover, certain peptides may possess anticancer activity. ${ }^{5}$ AMPs are generally defined as cationic, amphipathic peptides, with less than 50 amino acids, including multiple arginine and lysine residues $^{6}$ and show inhibitory concentrations (MIC) as low as $0.25-4 \mu \mathrm{g} / \mathrm{ml}^{7}$ They are widely distributed in nature, from insects to plants and animal species; at least 1972 AMPs have been identified so far (http://aps.unmc.edu/AP/main.php; May 2012).

Magainins are AMPs isolated from the skin of the African clawed frog Xenopus laevis. ${ }^{8,9}$ Magainins are comprised of 21-27 amino acid residues that create an $\alpha$-helical secondary structure characterized by separate cationic and hydrophobic faces. ${ }^{5}$ Magainin-2 (GIGKFLHSAKKFGKAFVGEIMNS), a polycationic peptide with a net positive charge of 3 , has been well studied for its killing action on various microorganisms, as well as on tumor cells. ${ }^{10-12}$ It acts by permeabilizing their membranes, either in a detergent-like manner or by making well-structured channels. ${ }^{13,14}$ Magainin-2 and its

Correspondence concerning this article should be addressed to M. Gama at fmgama@deb.uminho.pt. more potent synthetic analogs (magainins A, B, and G) cause the rapid lysis of both hematopoietic and solid tumor cell lines at concentrations 5- to 10-fold lower than those lytic for normal human peripheral blood lymphocytes or neutrophils. ${ }^{5}$

Many bacterial and fungal enzymes that hydrolyze insoluble carbohydrates share a common structure composed of a catalytic domain linked to a carbohydrate-binding module (CBM). CBMs that are specific for insoluble cellulose (cellulose binding domain-CBD) represent the predominant category. The CBMs can be grouped into distinctive families on the basis of amino acid sequence similarities ${ }^{15}$; 64 families of CBMs have been recognized so far (http://www.cazy.org/ fam/acc_CBM.html; May 2012).

Family-III CBDs normally comprise $\sim 150$ amino acids residues, have been identified in many different bacterial enzymes, and also in nonhydrolytic proteins. ${ }^{16}$ Clostridium thermocellum produces a multienzyme complex of cellulases and hemicellulases, termed the cellulosome, which is assembled by the scaffoldin protein CipA. Binding of the cellulosome to the plant cell wall is driven by the action of the CipA family 3 CBM (CBM3), which presents high affinity for crystalline cellulose. ${ }^{17} \mathrm{CBM} 3$ belongs to the all- $\beta$ family of proteins and is arranged in two antiparallel $\beta$ sheets that form a $\beta$ sandwich with jellyroll topology. ${ }^{16}$

AMPs have potential to provide an important breakthrough and form the basis for a new class of antibiotics. Since, AMPs are usually short peptides, chemical synthesis could be one approach for producing them. However, a costeffective and scalable method of active production is required in order to commercialize the bacterial peptides. Bacterial expression of heterologs proteins is an easy and inexpensive tool for producing large amounts of recombinant 


\section{pET-21a}

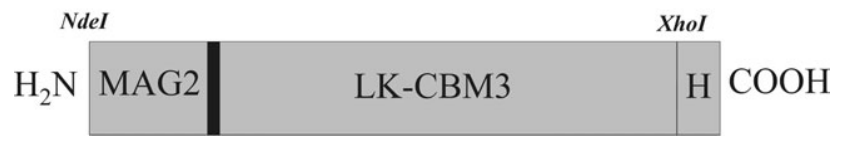

Figure 1. Schematic representation of MAG2-LK-CBM3 construction.

The AspPro site for chemical cleavage with formic acid is shown in black; H: His-tag.

proteins. ${ }^{18}$ Production of recombinant expression of AMPs in Escherichia coli is potentially limited because of their toxicity to host cells and susceptibility to proteolytic degradation, which can be avoided using fusion protein approach. ${ }^{19}$ There are several fusion partners (e.g., solubility-enhancing, aggregation-promoting, and self-cleavable carriers, etc), cleavage methods and optimization options for AMPs production in $E$. coli. $^{20}$ However, the very few works describing MAG2 expression in $E$. coli, including using fusing partners, ${ }^{21}$ may indicate that it is very difficult to produce MAG2 in bacteria. As Magainin displays high antibacterial and antitumor activities, ${ }^{11,12}$ the development of a method to obtain recombinant and functional Magainin but at low cost is crucial for its expansion as a therapeutic agent. ${ }^{18,19}$ Moreover, potent ana$\log$ s of MAG2 have been obtained by substitutions of glycine or serine with alanine residues and amidation of the C-terminus, which resulted in enhanced $\alpha$-helical structure and antimicrobial activity. Studies with pronase digestion suggested that the lower antimicrobial of MAG2 activity, when comparing to analogs, may be due to higher susceptibility to proteolysis in the presence of membranes. ${ }^{10}$ In this work, the fusion of MAG2 with the CBM3 was attempted as an approach for its large scale production and could also be used for the production of Magainin analogs.

\section{Materials and Methods}

\section{Construction of expression vectors}

The gene encoding CBM3 fused to the endogenous CipA $\mathrm{N}$-terminal linker sequence (LK) has previously been cloned in the expression vector pET-21a (Novagen), in our laboratory. ${ }^{17}$ The expression vector was constructed with MAG2 at the N-terminal (MAG2-LK-CBM3) of the pET-21a vector (Figure 1). This vector was constructed to allow the cloning of MAG2 at the N-terminal of the LK-CBM3 while keeping a C-terminal His 6-tag.

The nucleotide sequence of MAG2 was engineered to allow codon optimization in E. coli. The sequence encoding the peptide was included in the primers in fusion with the gene of a family 3 CBM. The pET-21a-LK-CBM3 was used as template. For the MAG2-LK-CBM3 construction, the following primers were used: 5'-GGA ATTC CAT ATG GGT ATT GGT AAA TTT CTG CAT AGC GCG AAA AAA TTT GGT AAA GCG TTT GTG GGT GAA ATT ATG AAC AGC GAT CCG ACA CCG ACC AAG GGA GCA-3' (forward primer) and $5^{\prime}$-CAC CTC GAG TTC TTT ACC CCA TAC AAG AAC-3' (reverse primer). NdeI, XhoI (MAG2-LK-CBM3) recognition sites are shown in bold. In order to allow the chemical cleavage with formic acid, proline and aspartate residues were introduced (underlined). PCR reactions were performed using the DNA polymerase VENT (Stratagene). The PCR reactions were performed as follows: preheating at $95^{\circ} \mathrm{C}$ for $2 \mathrm{~min}, 30$ cycles at $95^{\circ} \mathrm{C}$ for
$30 \mathrm{~s}, 30 \mathrm{~s}$ at $52^{\circ} \mathrm{C}$, and $30 \mathrm{~s}$ at $72^{\circ} \mathrm{C}$, followed by a final elongation stage at $72^{\circ} \mathrm{C}$ for $10 \mathrm{~min}$. The amplified product was recovered from $1 \%$ agarose gel, digested with $\mathrm{NdeI}$ and XhoI and ligated into pET-21a plasmids. The plasmid was sequenced to ensure that no mutations had occurred during PCR. Figure 1 represents MAG2-LK-CBM3 construction.

\section{Expression and purification of fusion protein}

The recombinant plasmid pET-21a-MAG2-LK-CBM3 was transformed into the E. coli strain BL21 (DE3) (Novagen) for protein expression. The bacterial strain was grown in Luria-Bertani broth (LB) containing $100 \mu \mathrm{g} / \mathrm{ml}$ of ampicillin, at $37^{\circ} \mathrm{C}$, to mid-exponential phase $\left(\mathrm{OD}_{595}\right.$ 0.6). Expression of the fusion protein was initiated by adding isopropyl$\beta$-D-thiogalactopyranoside (IPTG) at a final concentration of $1 \mathrm{~m} M$ and the culture was incubated overnight at $37^{\circ} \mathrm{C}$. Then, the cells were centrifuged at $6000 \mathrm{rpm}$ for $15 \mathrm{~min}$ at $4^{\circ} \mathrm{C}$, resuspended in $150 \mathrm{~m} M$ Tris- $\mathrm{HCl}, \mathrm{pH}$ 7.0, $20 \mathrm{mM} \mathrm{NaCl}$, $5 \mathrm{mM} \mathrm{CaCl}{ }_{2}\left(2 \mathrm{H}_{2} \mathrm{O}\right)$ buffer (CBM buffer) and sonicated in ice for $6 \mathrm{~min}$. The cells were centrifuged at 12,000 rpm, for 30 min at $4^{\circ} \mathrm{C}$ and the soluble fraction was collected.

The His 6-tagged recombinant protein was purified by immobilized metal ion affinity chromatography (IMAC), using $5 \mathrm{ml}$ Niquel His-Trap Columns (GE Health). The column charged with $0.1 \mathrm{M} \mathrm{NiSO}_{4}$ was equilibrated with $20 \mathrm{mM}$ of $\mathrm{Na}_{3} \mathrm{PO}_{4}, 500 \mathrm{~m} M \mathrm{NaCl}, 40 \mathrm{~m} M$ Imidazole, $\mathrm{pH}$ 7.4. The cell extract was loaded into the column, which was washed with the equilibration buffer. Finally, the recombinant protein were eluted with $20 \mathrm{~m} M \mathrm{Na}_{3} \mathrm{PO}_{4}, 500 \mathrm{mM} \mathrm{NaCl}, 300 \mathrm{~m} M$ Imidazole, $\mathrm{pH}$ 7.4. After purification, protein buffer was exchanged into CBM buffer, using PD10-columns (GE Health).

The recombinant protein was also purified on cellulose CF11 (Sigma), exploiting the CBM3 cellulose-binding properties, as follows: $20 \mathrm{ml}$ of cell-free extracts were mixed with $2 \mathrm{~g}$ of cellulose and incubated, with agitation, for $1 \mathrm{~h}$ at $4^{\circ} \mathrm{C}$. The cellulose with bound proteins was then centrifuged and washed 5 times with CBM buffer.

\section{Formic acid cleavage and MAG2 purification}

To cleave MAG2 of the recombinant protein, a $50 \%$ formic acid solution $(20 \mathrm{ml}$ of distilled water and $26 \mathrm{ml} 88 \%$ formic acid) was applied directly to cellulose with the adsorbed fusion protein. In the case of proteins purified by IMAC, formic acid was mixed with the purified protein (20 $\mathrm{ml}$ of pure protein and $26 \mathrm{ml}$ of formic acid $88 \%$ ). The mixture was then incubated for $24 \mathrm{~h}$, at $50^{\circ} \mathrm{C}$. The supernatant was separated after centrifugation at $12,000 \mathrm{rpm}$, for $30 \mathrm{~min}$, and lyophilized to remove formic acid. The cleavage was confirmed by SDS-PAGE using a $16.5 \%$ Tris-Tricine gel.

The purification of MAG2 was achieved by reverse-phase HPLC, using an YMC C18 preparative column $(250 \times 30 \mathrm{~mm})$ equilibrated with aqueous acetonitrile $(5 \%) / 0.1 \%$ trifluoracetic acid (TFA). The peptide was eluted using a linear gradient of acetonitrile from $5 \%$ to $90 \%$ at a flow rate of $5 \mathrm{ml} / \mathrm{min}$. The elution was monitored at $215 \mathrm{~nm}$. Several peaks were collected and analyzed by SDS-PAGE using a 16\% Tris-Tricine gel. The fraction corresponding to pure MAG2 was lyophilized.

The purification of MAG2 was also attempted through ultrafiltration in a Centricon with $5 \mathrm{kDa}$ molecular weight cut-off (Millipore). The filtrate was collected and analyzed by $16 \%$ Tris-Tricine gel SDS-PAGE. The concentration of the recombinant peptide was quantified using Waddell's method. ${ }^{22}$ 


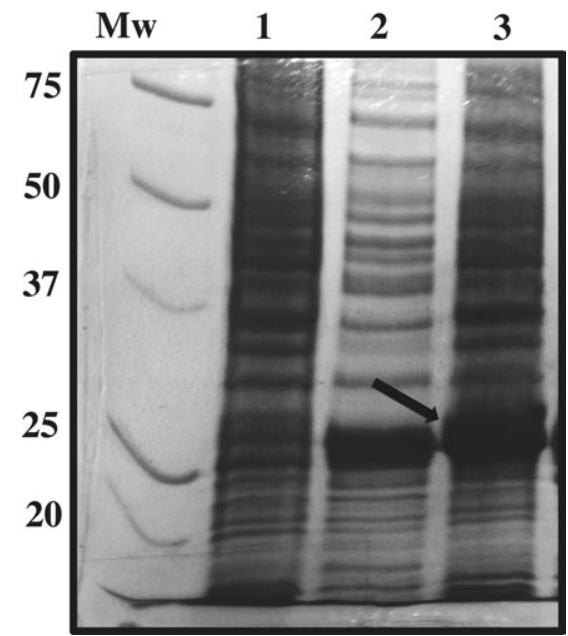

Figure 2. Expression of recombinant protein MAG2-LK-CBM3. $M_{\mathrm{w}}$, protein molecular weight marker; (1) before induction; (2) insoluble fraction; and (3) soluble fraction.

\section{MALDI-TOF mass spectrometry}

The formic acid cleavage of the recombinant proteins and the purity of MAG2 were evaluated by mass spectrometry at the Institute of Molecular Pathology and Immunology of the University of Porto (IPATIMUP). Sample was desalted and concentrated using microC18 ZipTips (Millipore, USA) accordingly to the manufacturer's protocol. The sample was eluted with the matrix $\alpha$-cyano-4-hydroxycinnamic acid (5 mg/ $\mathrm{ml}$ ) in $50 \%$ acetonitrile/ $0.1 \%$ TFA and spotted onto a stainless steel 192-well MALDI plate. After sample crystallization, mass spectrum acquisition was performed using a 4700 Proteomics Analyzer MALDI-TOF/TOF (Applied Biosystems, USA). Mass spectra were acquired in positive linear mode for $1-15 \mathrm{kDa}(\mathrm{m} / \mathrm{z})$ mass window and in positive reflector mode for the ranges 700-7000, 4000-5000, and 4585-4600 Da $(\mathrm{m} / \mathrm{z})$. External calibration of the mass spectrum was performed using Applied Biosystems Calibration Mix 3 standards.

\section{Antibacterial activity}

The antibacterial activity of the pure peptide was quantified in 96-well polypropylene microtiter plates, as described by Vogt et al., ${ }^{23}$ with some modifications. E. coli strain K12 was grown at $37^{\circ} \mathrm{C}$ in $\mathrm{LB}$ medium until mid-logarithmic phase $\left(\mathrm{OD}_{600} 0.5\right)$. The cells were then resuspended in $\mathrm{LB}$ at $2 \times 10^{7}$ and $2 \times 10^{6}$ cells $/ \mathrm{ml} ; 100 \mu \mathrm{l}$ of peptides, at different concentrations, were inoculated with $100 \mu \mathrm{l}$ of bacterial suspension, incubated overnight at $37^{\circ} \mathrm{C}$ and the bacterial growth was assessed by the measurement of optical density at $620 \mathrm{~nm}$. Each assay was repeated three times, using as reference sterile deionized water instead of the peptide solutions.

\section{Results and Discussion}

\section{Expression and purification of recombinant protein}

The antimicrobial peptide MAG2 was successfully cloned at the N-terminal of the LK-CBM3 in the expression vector pET-21a. After transformation of the recombinant plasmid into E. coli BL21 (DE3), several fermentation conditions, including induction temperature $\left(18,25,30\right.$, and $\left.37^{\circ} \mathrm{C}\right)$, IPTG concentration $(0.1,0.5$, and $1 \mathrm{~m} M)$, induction time (4 $\mathrm{h}$ and overnight), $\mathrm{OD}_{595 \mathrm{~nm}}$ at the induction (0.4 and 0.6)
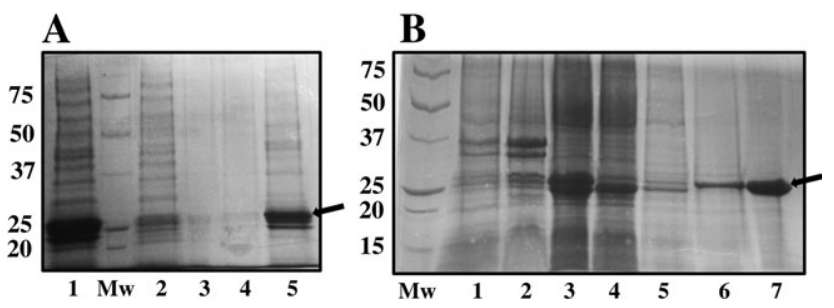

Figure 3. A: Purification of MAG2-LK-CBM3 on cellulose fibers.

$M_{\mathrm{w}}$, protein molecular weight marker; (1) total fraction; (2) unbound protein; (3) first cellulose wash; (4) fifth cellulose wash; (5) bound protein eluted with 1\% SDS. B: Purification of LK-CBM3-MAG2 by IMAC. $M_{\mathrm{w}}$, protein molecular weight marker; (1) uninduced cells; (2) insoluble fraction; (3) soluble fraction; (4) column filtrate; (5 and 6) column washes; 7, pure protein.

were tested, attempting to optimize the production of the recombinant protein in the soluble form. The fusion protein MAG2-LK-CBM3 ( $24 \mathrm{kDa})$ was successfully expressed in soluble form after induction at $37^{\circ} \mathrm{C}$ with $1 \mathrm{~m} M$ IPTG (Figure 2). Two bands that may correspond to the expressed proteins after induction were observed, either in soluble and insoluble fractions; however, according to the purification results (Figure 3), the recombinant MAG2-LK-CBM3 corresponds to the band with higher molecular weight (indicated with an arrow in Figure 2), therefore only a small amount of fusion protein was expressed under insoluble form.

There are two major problems in the expression of AMPs in E. coli: the cytoxicity of the peptides to the host and the sensitivity of peptides with positively charged amino acids to proteases. A common strategy for the production of recombinant peptides involves genetic attachment to a well expressed protein to generate a fusion protein. The protein acts to protect the peptide from proteolytic digestion and can protect the host from potential toxicity associated with some peptides. The high toxicity of the peptides usually leads to expression in inclusions bodies or in aggregate form. To overcome this situation, the use of a fusion partner is highly recommended. There are a number of fusion partner proteins available that differ in size and properties; some facilitate soluble expression while others promote the formation of inclusion bodies. ${ }^{24-26}$ Guerreiro et al. ${ }^{17}$ reported the soluble expression of the family $3 \mathrm{CBM}$ from $C$. thermocellumalso used in this work-fused to three different AMPs: LKLLKKL, LKKLLKKLKKLLKK, and porcine myeloid antibacterial peptide-23 (PMAP-23) RIIDLLWRVRRPQKPK FVTVWVR. Only the protein LKLLKKLLKLLKKLGG GK-LK-CBM3 was found to be insoluble when expressed by different $E$. coli strains, under a range of induction conditions. Also, the constructs with CBM fused to the human cathalicidin LL37 have been previously successfully expressed in our group. ${ }^{27,28}$ Therefore, although the solubility of AMPs fused to the CBM3 is rather unpredictable, the expression of the fusion proteins was, in all cases, successful. In this work, the expression of soluble magainin-2, fused at the N-terminus of LK-CBM3, was achieved. The family 3 cellulose-binding module was chosen as fusion partner considering the previously demonstrated successful overexpression of several CBM-AMPs, the simplicity of purification using cellulose as an affinity chromatography matrix, and also the low cost of cellulose, which makes this an attractive purification matrix, therefore we explored the recovery of the MAG2-LK-CBM3 using cellulose CF11 fibers. 
As demonstrated by Tomme et al., CBM3 binds cellulose with high affinity. In fact, the equilibrium affinity constant $\left(K_{\mathrm{a}}\right)$ for Avicel was reported to be $7.7 \times 10^{6} \mathrm{M}^{-1} \cdot{ }^{29}$ Figure 3 shows that the fusion of the peptide MAG2 did not affect the binding to cellulose. However, unlike the recombinant

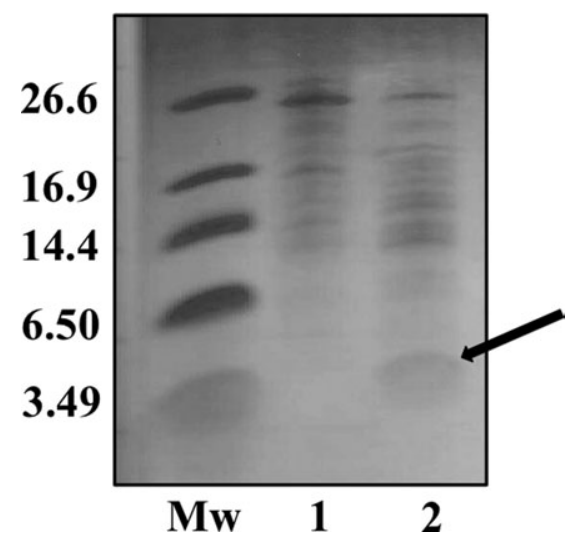

Figure 4. Formic acid cleavage of the recombinant protein MAG2-LK-CBM3.

$M_{\mathrm{w}}$, protein molecular weight marker; insoluble fraction of cleaved MAG2-LK-CBM3; 2, supernatant of cleaved MAG2LK-CBM3. protein described in the works listed above, in the case of MAG2-LK-CBM the purification of on cellulose was not fully effective due to unspecific binding of contaminating proteins, and we therefore explored purification using IMAC system by exploiting the histidine tag. This allowed the more efficient recovery of purified fusion protein as shown in Figure 3.

\section{Chemical cleavage of MAG2-LK-CBM3}

Formic acid was chosen for hydrolysis instead of thrombin or factor Xa proteases, to reduce production costs. After purification with cellulose, $50 \%$ formic acid was applied to cleave the AMP MAG2 from the fusion carrier, CBM3. The formic acid cleavage of MAG2 $(\sim 2.5 \mathrm{kDa})$ from the fusion partner LK-CBM3 was successful, as illustrated in Figure 4. After hydrolysis, the mixture was lyophilized to remove the formic acid. The protein was resuspended in ultrapure water and centrifuged to remove proteins degraded by the formic acid.

Figure 4 shows that a significant number of contaminants were present in the supernatant after the formic acid cleavage. Consequently, the supernatant containing the MAG2 peptide was purified by reverse-phase HPLC. The fractions corresponding to the major peaks (Figure 5A) were collected and the purity of the peptide was checked on $16.5 \%$ TrisTricine gel (Figure 5B).

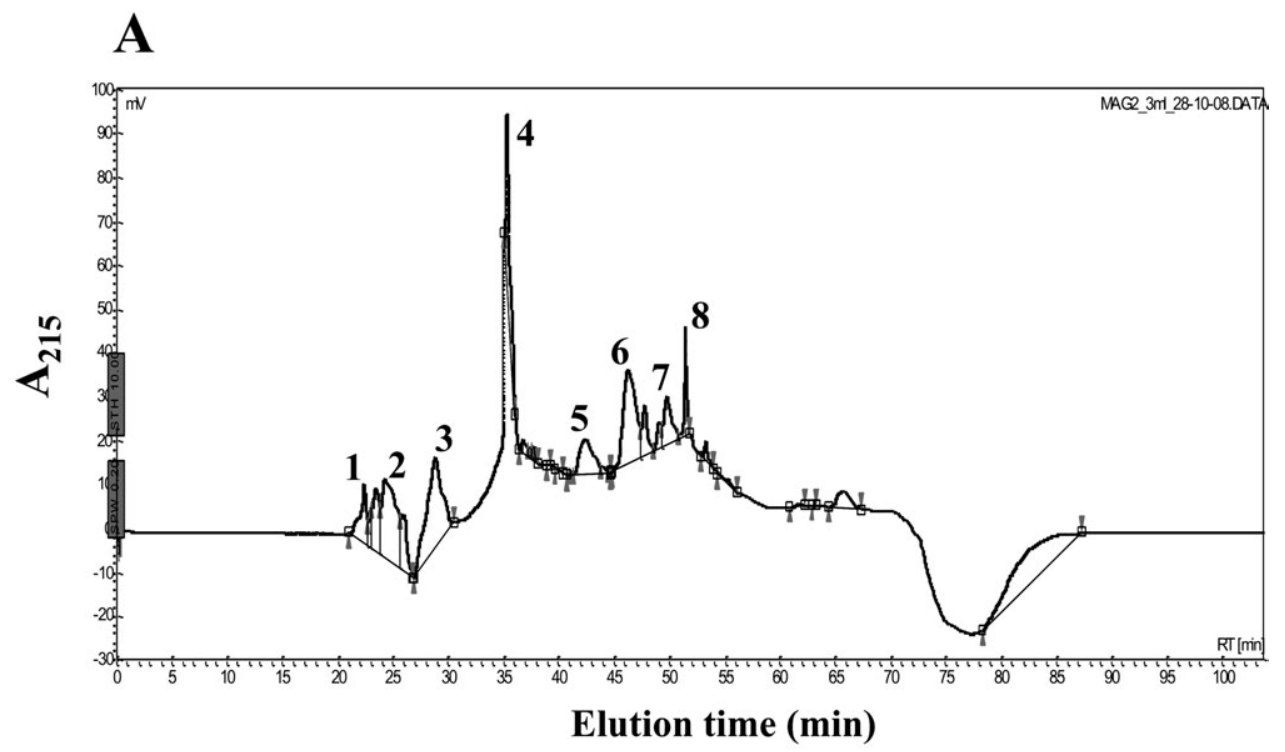

B

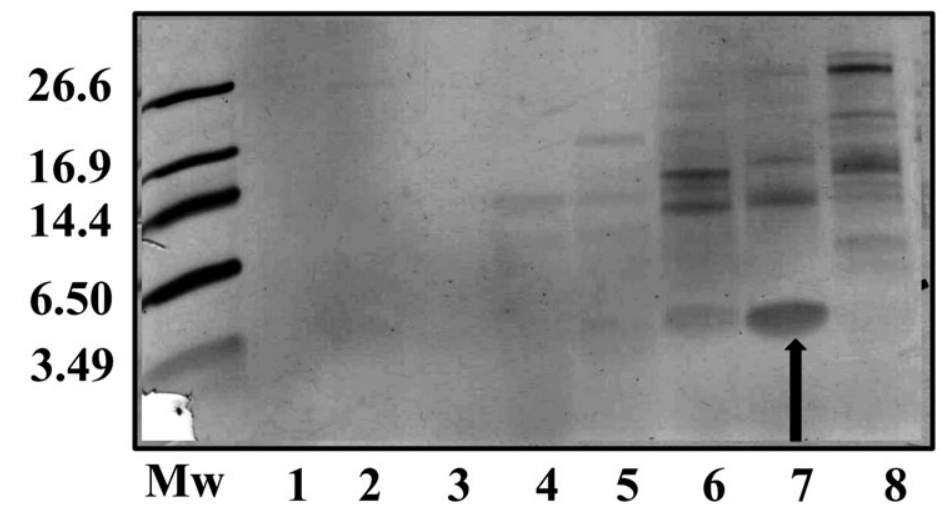

Figure 5. Reverse-phase HPLC chromatogram of MAG2-LK-CBM3 (A). RP-HPLC peak fractions (B). Mw, protein molecular weight marker; lanes 1-8, peak fractions of cleaved MAG2-LK-CBM3. 


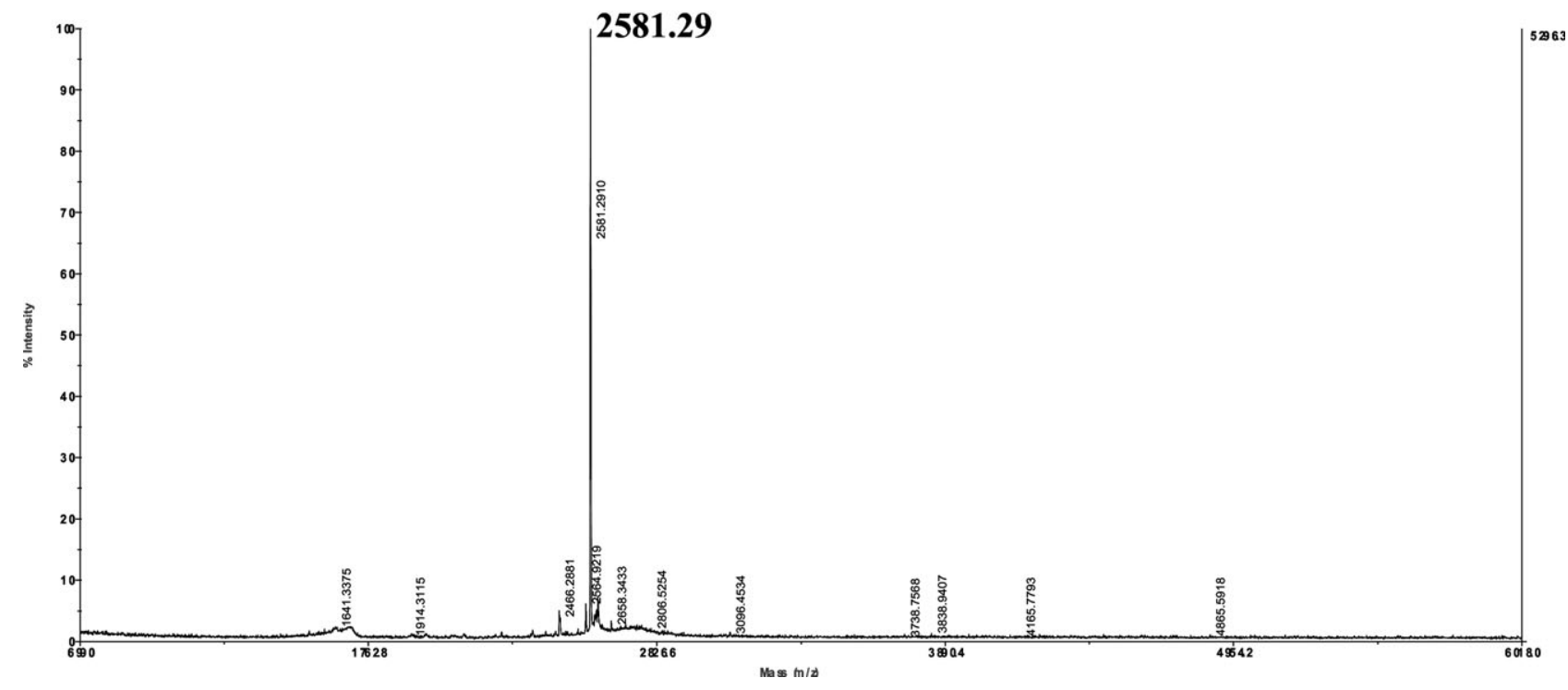

Figure 6. MALDI-TOF MS analysis of purified MAG2.

The measured molecular weight is very close to the predicted theoretical value (2582 Da).

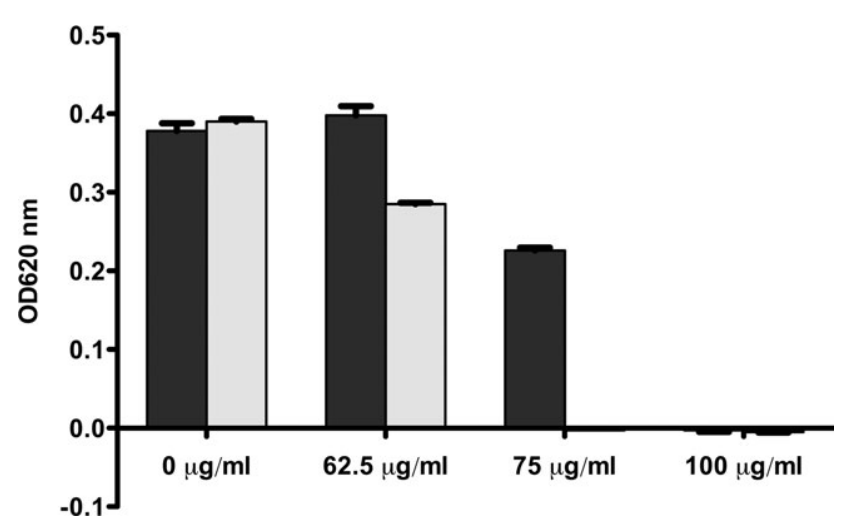

Figure 7. Antibacterial activity of MAG2 against $E$. coli K12.

Bacterial growth was inhibited at a concentration of $100 \mu \mathrm{g} / \mathrm{ml}$ $(39 \mu \mathrm{M})$ of recombinant MAG2 to an initial cell concentration of $1 \times 10^{6}$ (black gray) or $1 \times 10^{5}$ (light gray). Results are represented as mean SD of OD600 $\mathrm{nm}$.

The fraction with a retention time of about 50 min (peak 7) contained the mostly pure antimicrobial peptide MAG2. Some contaminant proteins were not efficiently removed by RP-HPLC and remained present in low amounts. To confirm the purity and molecular weight of the peptide, MALDI-TOF analysis was performed (Figure 6).

The peptide resulting from the hydrolysis has 24 amino acids with a C-terminal aspartic acid (MAG2-D), left by the chemical cleavage and a theoretical molecular weight of $2582 \mathrm{Da}$. The MALDI-TOF analysis confirmed the molecular weight of the recombinant peptide as well as its purity. This molecular weight indicates that the $\mathrm{N}$-terminal methionine from the translation process has been cleaved. Giglione et al. ${ }^{30}$ reported that $55-$ $70 \%$ of mature proteins are subjected to N-terminal Met excision and this was the case with MAG2-LK-CBM3.

\section{Antibacterial Activity of MAG2-LK-CBM3}

After the successful expression and purification of MAG2, its activity was tested against $E$. coli $\mathrm{K} 12$, using different protein concentration between 62.5 and $200 \mu \mathrm{g} / \mathrm{ml}$, in order to deter- mine the MIC of recombinant MAG2. The concentration of the peptide was quantified by UV spectroscopy using the Waddell's method. ${ }^{22}$ Figure 7 demonstrates that MAG2 has antimicrobial activity, with a MIC of about $100 \mu \mathrm{g} / \mathrm{ml}(\sim 39 \mu M)$, a value similar to the ones found in the in the literature. ${ }^{31-33}$ At lower concentration, MAG2 inhibited bacterial growth only partially, an effect dependent on the initial cellular density. The fusion protein MAG2-CBM3 did not show antimicrobial activity (results not shown).

The results suggest that the negatively charged C-terminal aspartic acid, left from acid cleavage, does not affect the antibacterial activity of the recombinant protein. Since, AMPs interact by electrostatic forces with the negatively charged bacterial membrane phospholipids, eventually leading to its disruption, ${ }^{34}$ the lower net charge of the produced MAG2 $(+2)$ could affect is antibacterial activity, but actually this was not the case.

To date, the successful cloning, expression, and purification of the AMP Magainin-2 in bacteria has not been reported. Barrell et al. reported the successful expression of MAG2 fused to the well-known thioredox into raise antibodies. ${ }^{21}$ However, they did not cleave and purify MAG2 from its expression partner. A Magainin analogs (MSI-344) was expressed and purified with good yields from $E$. coli inclusion bodies. The recombinant peptide kept its antibacterial activity. ${ }^{35,36}$ In a different approach, Fan and Li successfully expressed MAG2 in a mammalian cell system at high productivity and efficiency. ${ }^{37}$ The very few works reported may indicate that it is very difficult to produce MAG2 in bacteria. Here we presented a strategy to produce active MAG2, which could be used to produce MAG2 analogs or other AMPs. One challenge with this approach is determining efficient elution conditions that do not result in contaminant proteins during purification using CF11 cellulose fibers. Improvements in peptide recovery might be achieved by combining cellulose affinity with on column cleavage followed by immobilized metal affinity chromatography to remove contaminants.

\section{Conclusions}

Some AMPs can physically attack the microbial membranes to kill microbes, even those that present antibiotic- 
resistant mechanisms. These peptides have been the focus of increasing interest, arising as excellent candidates for new types of antibiotics. Production of peptide antibiotics at a large scale is a significant challenge for developing commercial products. Expression of recombinant AMPs is not always successful, either because of their activity to the host and/or proteolysis of the recombinant peptides during synthesis. In this work, the peptide MAG2 was successfully expressed, cleaved and purified. The isolated peptide bears antibacterial activity. The CBM3 utilization as fusion partner appears to be very effective for production and purification of AMPs.

\section{Literature Cited}

1. Rossi LM, Rangasamy P, Zhang J, Qiu XQ, Wu GY. Research advances in the development of peptide antibiotics. J Pharm Sci. 2008;97:1060-1070.

2. Ajesh K, Sreejith K. Peptide antibiotics: an alternative and effective antimicrobial strategy to circumvent fungal infections. Peptides. 2009;30:999-1006.

3. Murakami T, Niwa M, Tokunaga F, Miyata T, Iwanaga S. Direct virus inactivation of tachyplesin I and its isopeptides from horseshoe crab hemocytes. Chemotherapy. 1991;37:327-334.

4. Morimoto M, Mori H, Otake T, Ueba N, Kunita N, Niwa M, Murakami T, Iwanaga S. Inhibitory effect of tachyplesin I on the proliferation of human immunodeficiency virus in vitro. Chemotherapy. 1991;37:206-211.

5. Hoskin DW, Ramamoorthy A. Studies on anticancer activities of antimicrobial peptides. Biochim Biophys Acta. 2008;1778:357-375.

6. Powers JP, Hancock RE. The relationship between peptide structure and antibacterial activity. Peptides. 2003;24:1681-1691.

7. Hancock RE, Diamond G. The role of cationic antimicrobial peptides in innate host defences. Trends Microbiol. 2000;8:402-410.

8. Zasloff M. Magainins, a class of antimicrobial peptides from Xenopus skin: isolation, characterization of two active forms, and partial cDNA sequence of a precursor. Proc Natl Acad Sci U S A. 1987;84:5449-5453.

9. King JD, Mechkarska M, Coquet L, Leprince J, Jouenne T, Vaudry H, Takada K, Conlon JM. Host-defense peptides from skin secretions of the tetraploid frogs Xenopus petersii and Xenopus pygmaeus, and the octoploid frog Xenopus lenduensis (Pipidae). Peptides. 2012;33:35-43.

10. Westerhoff HV, Juretic D, Hendler RW, Zasloff M. Magainins and the disruption of membrane-linked free-energy transduction. Proc Natl Acad Sci U S A. 1989;86:6597-6601.

11. Cruciani RA, Barker JL, Zasloff M, Chen HC, Colamonici O. Antibiotic magainins exert cytolytic activity against transformed cell lines through channel formation. Proc Natl Acad Sci U S A. 1991;88:3792-3796.

12. Gallucci E, Meleleo D, Micelli S, Picciarelli V. Magainin 2 channel formation in planar lipid membranes: the role of lipid polar groups and ergosterol. Eur Biophys J. 2003;32:22-32.

13. Cruciani RA, Barker JL, Durell SR, Raghunathan G, Guy HR, Zasloff M, Stanley EF. Magainin 2, a natural antibiotic from frog skin, forms ion channels in lipid bilayer membranes. Eur $J$ Pharmacol. 1992;226:287-296.

14. Grant E Jr, Beeler TJ, Taylor KM, Gable K, Roseman MA. Mechanism of magainin 2a induced permeabilization of phospholipid vesicles. Biochemistry. 1992;31:9912-9918.

15. Gilkes NR, Henrissat B, Kilburn DG, Miller RC Jr, Warren RA. Domains in microbial beta-1, 4-glycanases: sequence conservation, function, and enzyme families. Microbiol Rev. 1991;55:303-315.

16. Tormo J, Lamed R, Chirino AJ, Morag E, Bayer EA, Shoham Y, Steitz TA. Crystal structure of a bacterial family-III cellulose-binding domain: a general mechanism for attachment to cellulose. EMBO J. 1996;15:5739-5751.
17. Guerreiro CI, Fontes CM, Gama M, Domingues L. Escherichia coli expression and purification of four antimicrobial peptides fused to a family 3 carbohydrate-binding module (CBM) from Clostridium thermocellum. Prot Expr Purif. 2008;59:161-168.

18. Wright O, Yoshimi T, Tunnacliffe A. Recombinant production of cathelicidin-derived antimicrobial peptides in Escherichia coli using an inducible autocleaving enzyme tag. $N$ Biotechnol. 2012;29:352-358.

19. Zorko M, Jerala R. Production of recombinant antimicrobial peptides in bacteria. Methods Mol Biol. 2010;618:61-76.

20. Li Y. Recombinant production of antimicrobial peptides in Escherichia coli: a review. Prot Expr Purif. 2011;80:260-267.

21. Barrell PJ, Liew OW, Conner AJ. Expressing an antibacterial protein in bacteria for raising antibodies. Prot Expr Purif. 2004;33:153-159.

22. Waddell WJ. A simple ultraviolet spectrophotometric method for the determination of protein. J Lab Clin Med. 1956;48:311-314.

23. Vogt TC, Bechinger B. The interactions of histidine-containing amphipathic helical peptide antibiotics with lipid bilayers. The effects of charges and pH. J Biol Chem. 1999;274:29115-29121.

24. Ingham $\mathrm{AB}$, Moore RJ. Recombinant production of antimicrobial peptides in heterologous microbial systems. Biotechnol Appl Biochem. 2007;47:1-9.

25. Garcia-Fruitos E. Inclusion bodies: a new concept. Microb Cell Fact. 2010;9:80.

26. Rodriguez-Carmona E, Cano-Garrido O, Seras-Franzoso J, Villaverde A, Garcia-Fruitos E. Isolation of cell-free bacterial inclusion bodies. Microb Cell Fact. 2010;9:71.

27. Ramos R, Domingues L, Gama M. Escherichia coli expression and purification of LL37 fused to a family III carbohydrate-binding module from Clostridium thermocellum. Prot Expr Purif. 2010;71:1-7.

28. Ramos R, Silva JP, Rodrigues AC, Costa R, Guardao L, Schmitt F, Soares R, Vilanova M, Domingues L, Gama M. Wound healing activity of the human antimicrobial peptide LL37. Peptides. 2011;32:1469-1476.

29. Tomme P, Boraston A, McLean B, Kormos J, Creagh AL, Sturch K, Gilkes NR, Haynes CA, Warren RA, Kilburn DG. Characterization and affinity applications of cellulose-binding domains. J Chromatogr B Biomed Sci Appl. 1998;715:283-296.

30. Giglione C, Boularot A, Meinnel T. Protein N-terminal methionine excision. Cell Mol Life Sci. 2004;61:1455-1474.

31. Sovadinova I, Palermo EF, Huang R, Thoma LM, Kuroda K. Mechanism of polymer-induced hemolysis: nanosized pore formation and osmotic lysis. Biomacromolecules. 2011;12:260-268.

32. Sovadinova I, Palermo EF, Urban M, Mpiga P, Caputo GA, Kuroda K. Activity and mechanism of antimicrobial peptide-mimetic amphiphilic polymethacrylate derivatives. Polymers. 2011;3:1512-1532.

33. Melo MN, Ferre R, Castanho MA. Antimicrobial peptides: linking partition, activity and high membrane-bound concentrations. Nat Rev Microbiol. 2009;7:245-250.

34. Dathe M, Nikolenko H, Meyer J, Beyermann M, Bienert M. Optimization of the antimicrobial activity of magainin peptides by modification of charge. FEBS Lett. 2001;501:146-150.

35. Hwang SW, Lee JH, Park HB, Pyo SH, So JE, Lee HS, Hong SS, Kim JH. A simple method for the purification of an antimicrobial peptide in recombinant Escherichia coli. Mol Biotechnol. 2001;18:193-198.

36. Lee JH, Kim JH, Hwang SW, Lee WJ, Yoon HK, Lee HS, Hong SS. High-level expression of antimicrobial peptide mediated by a fusion partner reinforcing formation of inclusion bodies. Biochem Biophys Res Commun. 2000;277:575-580.

37. Fan B, Li N. Design and synthesis of a Magainin2 fusion protein gene suitable for a mammalian expression system. Transgenic Res. 2009;18:99-112.

Manuscript received May 28, 2012, and revision received Aug. 28, 2012. 